\title{
PERKEMBANGAN FISIK ANAK, PROBLEM DAN PENANGANANNYA
}

\author{
Wiwit Eka Winarsih \\ winarsihwiwit88@gmail.com \\ IAIN Jember
}

\begin{abstract}
Man sano in carpore sano (in a healthy body there is a healthy soul), physical development is usually marked by changes in height and weight, as well as body shape and brain development. If the child's physical development develops well, it will certainly affect their motor skills. Likewise with children whose physical development is impaired, it will have an impact on the disruption of the child's motor skills. Therefore, this paper will discuss three important issues, first how the understanding and characteristics of children's physical development, second, what are the stages of children's physical development and third, what are the problems of children's physical development and how to deal with them. This paper is in the form of a literature review by digging from various sources of books and journals, in order to obtain a comprehensive understanding of the meaning and characteristics of children's physical development, stages of children's physical development, problems and handling of children's physical development.

Keywords: physical development, problems and handling
\end{abstract}

\begin{abstract}
Abstrak : Man sano in carpore sano (di dalam tubuh yang sehat terdapat jiwa yang sehat), Perkembangan fisik lazimnya ditandai dengan perubahan pada tinggi dan berat badan, serta bentuk tubuh dan juga perkembangan otak. Jika perkembangan fisik anak berkembang dengan baik tentu akan berpengaruh pada keterampilan motoriknya. Begitupun dengan anak yang perkembangan fisiknya mengalami gangguan, akan berdampak pada terganggunya kemampuan motorik anak tersebut. Oleh karena itu paper ini akan membahas tiga permasalahan penting pertama bagaimana pengertian dan karakreristik perkembangan fisik anak, kedua apa saja tahapan perkembangan fisik anak dan ketiga apa saja problem perkembangan fisik anak serta bagaimana penanganannya. Paper ini berbentuk kajian kepustakaan dengan menggali dari berbagai sumber buku dan jurnal, sehingga didapatkan pemahaman yang komprehensif tentang pengertian dan karekteristik perkembangan fisik anak, tahap perkembangan fisik anak, dan problem serta penanganan perkembangan fisik anak
\end{abstract}

Kata Kunci : Perkembangan fisik, problem dan penanganannya

\section{Pendahuluan}

Manusia terdiri dari fisik dan psikhis. Fisik merupakan tempat berkembang berbagai perkembangan manusia. Di dalam fisik terjadi perkembangan kognitif, sosial, moral, agama, dan bahasa. Fisik merupakan tempat bagi perkembangan psikis manusia. Oleh sebab itu ada pepatah dalam Bahasa Latin yang menyatakan: Man sano in carpore sano (di dalam tubuh yang sehat terdapat jiwa yang sehat) ${ }^{1}$.

Perkembangan adalah bertambahnya kemampuan (skill) dalam struktur dan fungsi tubuh yang lebih kompleks dalam pola yang teratur dan dapat diramalkan, sebagai hasil dari proses

${ }^{1}$ Dr. Masganti, Perkembangan Peserta Didik, (Medan: Perdana Publishing, 2012) 66 
pematangan. Fisik atau tubuh manusia merupakan sistem organ yang kompleks dan sangat mengagumkan. Semua organ ini terbentuk pada periode pranatal (dalam kandungan). Perkembangan fisik atau yang disebut juga pertumbuhan biologis (biological growth) merupakan salah satu aspek penting dari perkembangan individu, yang meliputi meliputi perubahanperubahan dalam tubuh (seperti: pertumbuhan otak, hormon, dll), dan perubahan-perubahan dalam cara-cara individu dalam menggunakan tubuhnya (seperti perkembangan keterampilan motorik dan perkembangan seksual), disertai perubahan dalam kemampuan fisik (seperti penurunan fungsi jantung, penglihatan dan sebagainya).

Bagi seorang guru, mengetahui dan memahami perkembangan pserta didik sangatlah diperlukan. Pemahaman guru yang benar terhadap perkembangan peserta didik akan menuntun guru membuat disain pembelajaran yang cocok untuk peserta didik. Disain pembelajaran yang cocok dengan perkembangan peserta didik akan menghasilkan pembelajaran yang maksimal. Pembelajaran yang tidak memperhatikan perkembangan peserta akan membuat peserta bosan atau frustrasi. Jika peserta didik bosan dan frustrasi, para guru juga akan tertular rasa bosan dan frustrasi ketika mengajar. Dasar pikir ini yang menjadikan pengetahuan tentang perkembangan peserta didik merupakan salah satu komponen dari kompetensi pedagogik seorang guru.

Begitu juga dengan berbagai problem dan permasalahan tentang perkembangan fisik anak yang biasa terjadi juga harus diketahui oleh guru ataupun orang tua sejak dini, hal ini penting karena dengan begitu akan lebih cepat dalam penanganan dan penanggulangan problem tersebut. Oleh karena itu, paper ini akan menjelaskan tentang perkembangan fisik anak, yang meliputi pengertian, tahapan perkembangan, faktor yang mempengaruhi perkembangan serta beberapa problem perkembangan fisik sekaligus penenganannya.

\section{Kajian teori}

\section{Pengertian dan Karakteristik Perkembangan Fisik Anak}

Perkembangan fisik adalah pertumbuhan dan perubahan yang terjadi pada tubuh seseorang. Perubahan yang paling jelas terlihat adalah perubahan pada bentuk dan ukuran tubuh seseorang.masa kanak kanak adalah masa terpanjang dalam rentang kehidupan, saat dimana individu sangat bergantung kepada orang lain dan masa ini dimulai setelah masa bayi yang penuh dengan ketergantungan yakni kira - kira usia nol sampai dua tahun. selanjutnya akan memasuki masa awal anak anak(2- 6 tahun) dan masa akhir anak - anak usia 6 sampai 12 tahun.Dengan demikian awal masa kanak- kanak dimulai sebagai penutup masa bayi dan duganti dengan kemandirian. 
Perkembangan fisik meliputi perkembangan motorik,(motor development) adalah perubahan yang terjadi secara progressif pada kontrol dan kemampuan untuk melakukan gerakan yang diperoleh melalui interaksi antara faktor kematangan (maturation) dan latihan atau pengalaman (experiences) selama kehidupan yang dapat dilihat melalui perubahan/pergerakan yang dilakukan. ${ }^{2}$

Sedangkan Hurlock $^{3}$ menjelaskan bahwa perkembangan motorik adalah perkembangan pengendalian gerakan jasmani melalui kegiatan pusat saraf, urat saraf, dan otot yang terkoordinasi. Sebelum perkembangan terjadi anak tidak akan berdaya. Kondisi tersebut akan berubah secara cepat pada usia 4-5 tahun pertama kehidupan pasca lahir. Anak dapat mengendalikan gerakan yang kasar. Gerakan tersebut melibatkan anggota badan yang luas yang digunakan untuk berjalan, melompat, berlari, berjinjit, berenang, dan sebagainya. Setelah berumur 5 tahun terjadi perkembangan yang besar dalam pengendalian koordinasi yang lebih baik yang melibatkan bagian otot yang lebih kecil yang digunakan untuk menggenggam, melempar, menangkap bola, menulis, dan sebagainya.

Perkembangan motorik sangat berkaitan erat dengan kegiatan fisik. Motorik merupakan perkembangan pengendalian gerakan tubuh melalui kegiatan yang terkoordinir antara susunan saraf, otak, dan spinal cord. Perkembangan motorik terbagi menjadi dua yaitu motorik kasar dan motorik halus. Motorik kasar adalah aspek yang berhubungan dengan pergerakan dan sikap tubuh. Motorik halus adalah aspek yang berhubungan dengan kemampuan anak untuk mengamati sesuatu, melakukan gerakan yang melibatkan bagian-bagian tubuh tertentu dan dilakukan otot-otot kecil, tetapi memerlukan koordinasi yang cermat.

Perkembangan fisik atau tubuh manusia merupakan sistem organ yang kompleks dan sangat mengagumkan. Kuhlen dan Thompson mengemukakan bahwa perkembangan fisik individu meliputi empat aspek, yaitu:

1. Sistem saraf yang sangat mempengaruhi perkembangan kecerdasan dan emosi;

2. Otot-otot yang mempengaruhi perkembangan kekuatan dan kemampuan motorik;

3. Kelenjar Endoktrin, yang menyebabkan munculnya pola-pola tingkah laku baru, seperti pada usia remaja berkembang perasaan senang untuk aktif dalam suatu kegiatan yang sebagian anggotanya terdiri atas lawan jenis;

4. Struktur fisik/tubuh yang meliputi tinggi berat dan proporsi. ${ }^{4}$

Pada masa anak - anak ini orangtua sering kali menyebut massa ini adalah masa yang penuh masalah, atau usia sulit, pada masa bayi masalah hanya berkisar mada masalah fikik bayi,

\footnotetext{
${ }^{2}$ Rini Hildayani. Psikologi Perkembangan Anak. (Tangerang: Universitas Terbuka, 2016) 3

${ }^{3}$ Hurlock, Elizabeth B, Developmental P sychology , 1980, Terj. Istiwidayanti dan Soedjarwo, P sikologi P erkembangan Sepanjang Rentang Kehidupan , Jakarta: Erlangga, 151

${ }^{4}$ Hurlock, Elizabeth B, Developmental... 152.
} 
tetapi pada masa anak anak terjadi masalah prilaku yang lebih menyulitkan daripada malalah perawatan fisik karena pada masa ini anak memgalami perkembangan fisik dan kepribadian. sedangkan ahli psikolongi menyebut masa anak-anak ini dengan usia meniru dan usia kreatif, senang bergerak, senang bekerja dalam kelompok, dan senang praktik langsung ${ }^{5}$ Berkaitan dengan konsep tersebut maka dapat dijabarkan:

1. Masa anak anak adalah masa bermain artinya anak anak lebih senang Bermain Pendidik diharuskan paham dengan perkembangan anak, memberikan aktifitas fisik dengan model bermain. Materi pembelajaran dibuat dalam bentuk games, terutama pada siswa SD kelas bawah (kelas $1 \mathrm{~s} / \mathrm{d}$ 3) yang masih cukup kental dengan zona bermain. Sehingga rancangan model pembelajaran berkonsep bermain yang menyenangkan, namun tetap memperhatikan ketercapaian materi ajar.

2. Anak usia SD senang bergerak Anak usia SD berbeda dengan orang dewasa yang betah duduk berjam-jam, namun anak-anak berbeda bahkan kemungkinan duduk tenang maksimal 30 menit. Pendidik berperan untuk membuat pembelajaran yang senantiasa bergerak dinamis, permainan menarik memberi stimulus pada minat gerak anak menjadi tinggi

3. Anak usia SD senang beraktifitas kelompok Anak usia SD umumnya mengelompok dengan teman sebaya atau se-usianya. Konsep pembelajaran kelas dapat dibuat model tugas kelompok, pendidik memberi materi melalui tugas sederhana untuk diselesaikan bersama. Tugas tersebut dalam bentuk gabungan unsur psikomotor (aktifitas gerak) yang melibatkan unsur kognitif. Misal anak usia SD diberi tugas materi gerak sederhana menjelaskan menembak bola (shooting), maka untuk memperoleh jawaban mereka akan mempraktikkan dahulu kemudian memaparkan sesuai kemampuan mereka

4. Anak usia SD senang praktik langsung. Anak usia sekolah dasar, memiliki karakteristik senang melakukan hal secara model praktikum, bukan teoritik. Berdasarkan ketiga konsep kesenangan sebelumnya ( senang bermain, bergerak, berkelompok) anak usia SD, tentu sangat efektif dikombinasikan dengan praktik langsung. Pendidik memberikan pengalaman belajar anak secara langsung, sehingga pembelajaran model teori klasikal tidak terlalu diperlukan atau diberikan saat evaluasi.

\section{Metode penelitian}

\footnotetext{
5 Abdul Alim. (2009). Permainan Mini Tenis untuk pembelajaran pendidikan Jasmani Olahraga dan Kesehatan Siswa di Sekolah Dasar. JPJI. Vol 6. No. 2. Nov 2009. Hlmn.82
} 
Paper ini merupakan library research atau kajian kepustakaan yaitu mengumpulkan data dengan cara menggali dari berbagai sumber buku dan jurnal, sehingga didapatkan pemahaman yang komprehensif tentang pengertian dan karekteristik perkembangan fisik anak, tahap perkembangan fisik anak, dan problem serta penanganan perkembangan fisik anak. Data primer yang digunakan adalah berbagai buku yang berkaitan langsung dengan topik penelitian, sedangkan data sekunder menggunakan berbagai buku penunjang. Sedangkan analisis yang digunakan menggunakan content analysis, atau analisis isi yaitu dengan mengkaji dan memadukan isi pembahasan secara mendalam dari berbagai sumber

\section{Hasil Dan Pembahasaan}

\section{Tahapan Tahapan Perkembangan Fisik Anak}

Perkembangan fisik yang baik dan berjalan sempurna sesuai dengan tahapan usia nya tidak terlepas dari makanan-makanan yang bergizi, sehingga dalam perekembangannya anak tidak mengalami hambatan baik pertumbuhan maupun perkembangan

Perkembangan fisik anak anak dimulai pada masa bayi sampai masa anak anak berakhir. Pertumbuhan fisik pada masa anak-anak relatif seimbang. Peningkatan berat badan anak lebih banyak dari pada panjang badannya. Peningkatan berat badan anak terjadi terutama karena bertambahnya ukuran sistem rangka, otot dan ukuran beberapa organ tubuh lainnya. Pertumbuhan dan perkembangan fisik pada masa anak-anak terdiri dari pertumbuhan dan perkembangan motorik kasar dan motorik halus. Perkembangan motorik kasar merupakan perkembangan kemampuan anak menggunakan seluruh anggota badan (otot-otot besar) untuk melakukan sesuatu.

Di samping anak-anak juga mengalami berbagai perkembangan penglihatan, pendengaran, penciuman, dan rasa sakit. Berbeda dengan pendapat sebagian ahli yang menyatakan anak yang baru lahir belum dapat melihat, sebuah penelitian menunjukkan bawa bayi baru lahir dapat melihat dengan jarak penglihatan $19 \mathrm{~cm}$. Mereka dapat melihat pada garis melengkung dan lurus, juga pada benda-benda yang berwarna dan terang. Pendengaran anak lebih dahulu berkembang dari penglihatan. Bayi baru lahir dapat langsung mendengar dan dapat bereaksi terhadap titiknada, volume, dan irama suara dengan baik. Bayi memiliki ambang pendengaran 10 sampai 20 desibel lebih tinggi dari orang dewasa. Inilah mungkin yang menyebabkan disunatkan membacakan azan atau iqamah pada bayi yang baru lahir. Beberapa perkembangan motorik kasar bayi dari usia 4-18 bulan sebagai berikut:.

\footnotetext{
${ }^{6}$ Dr. Masganti, Perkembangan Peserta Didik, (Medan: Perdana Publishing, 2012) 68
} 
Tabel Perkembangan motorik kasar bayi usia 0-12 Bulan $^{7}$

\begin{tabular}{|c|c|c|}
\hline \multirow{3}{*}{1.} & \multirow{3}{*}{$\begin{array}{c}0-3 \\
\text { Bulan }\end{array}$} & $\begin{array}{l}\text { Melakukan gerakan menoleh ke kanan/ } \\
\text { kiri atau sebaliknya }\end{array}$ \\
\hline & & Mengangkat kepala setinggi 45 derajat pada posisi tengkurap \\
\hline & & $\begin{array}{l}\text { Menggerakkan kepala dari kiri ke tengah, dari tengah ke kanan atau } \\
\text { sebaliknya pada posisi tengkurap, telentang atau digen- dong }\end{array}$ \\
\hline \multirow[b]{3}{*}{2.} & \multirow{3}{*}{$\begin{array}{l}3-6 \\
\text { Bulan }\end{array}$} & Mampu merayap \\
\hline & & Mampu merangkak \\
\hline & & $\begin{array}{l}\text { Dapat menjaga keseimbangan pada } 3 \text { titik tumpu, yang merupakan } \\
\text { tantangan keseimbangan kesiapan duduk ( } 1 \text { lengan } 2 \text { tungkai atau } 2 \text { lengan } \\
1 \text { tungkai) }\end{array}$ \\
\hline \multirow{5}{*}{3.} & \multirow{5}{*}{$\begin{array}{c}6-9 \\
\text { Bulan }\end{array}$} & Mampu duduk \\
\hline & & Mampu merangkak meraih mainan atau mendekati seseorang \\
\hline & & $\begin{array}{l}\text { Mampu mengangkat diri, bertumpu pada dua kaki (bipedal), berjalan } \\
\text { merambat pada benda (meja, kursi, atau benda lain yang aman) }\end{array}$ \\
\hline & & Mampu memindahkan benda dari satu tangan ke tangan lainnya \\
\hline & & Mampu berjalan $2-3$ langkah \\
\hline \multirow{5}{*}{4} & \multirow{5}{*}{$\begin{array}{c}9- \\
12 \\
\text { bulan }\end{array}$} & Mampu mengangkat benda ke posisi berdiri \\
\hline & & $\begin{array}{l}\text { Mampu belajar berdiri dengan berpega- ngan di kursi, meja atau benda lain } \\
\text { yang aman dan kuat }\end{array}$ \\
\hline & & $\begin{array}{l}\text { Mampu melakukan gerakan lengan mengayun mengambil obyek (menyekop, } \\
\text { mendayung, mencangkul) dengan dua lengan }\end{array}$ \\
\hline & & Mampu menggerakan bahu pada ruang gerak sendi maksimal \\
\hline & & Mampu melakukan gerakan memukul berirama \\
\hline \multirow{3}{*}{5} & \multirow[t]{3}{*}{$\begin{array}{l}12-18 \\
\text { bulan }\end{array}$} & $\begin{array}{l}\text { Berjalan sendiri. Naik tangga atau tempat yang lebih tinggi dengan } \\
\text { merangkak }\end{array}$ \\
\hline & & Menendang bola ke arah depan \\
\hline & & Berdiri dengan satu kaki selama satu detik \\
\hline \multirow{4}{*}{6} & \multirow{4}{*}{$\begin{array}{l}18-24 \\
\text { bulan }\end{array}$} & Melompat di tempat \\
\hline & & Naik tangga atau tempat yang lebih tinggi dengan berpegangan \\
\hline & & . Berjalan mundur beberapa langkah \\
\hline & & Menarik benda yang tidak terlalu berat (kursi kecil). \\
\hline
\end{tabular}

7 Sumber : Pengembangan Program Stimulasi Perkembangan Motorik Kasar Anak Usia 0 - <3 Tahun, BPPAUDNI Regional II Surabaya, 2014

60 Wiwit Eka Winarsih- Perkembangan Fisik Anak, Problem dan Penanganannya 


\begin{tabular}{|c|c|c|}
\hline \multirow{5}{*}{7} & \multirow{5}{*}{$\begin{array}{l}2-3 \\
\text { tahun }\end{array}$} & Berjalan sambil berjinjit \\
\hline & & Melompat ke depan dan ke belakang dengan dua kaki \\
\hline & & Melempar dan menangkap bola \\
\hline & & Menari mengikuti irama \\
\hline & & $\begin{array}{l}\text { Naik-turun tangga atau tempat yang lebih tinggi/rendah dengan } \\
\text { berpegangan }\end{array}$ \\
\hline \multirow{5}{*}{8} & \multirow{5}{*}{$\begin{array}{l}3-5 \\
\text { tahun }\end{array}$} & 1.Berlari sambil membawa sesuatu yang ringan (bola). 2. 3.. 4.5 \\
\hline & & Naik-turun tangga atau tempat yang lebih tinggi dengan kaki bergantian. \\
\hline & & Meniti di atas papan yang cukup lebar \\
\hline & & $\begin{array}{l}\text { Melompat turun dari ketinggian kurang lebih } 20 \mathrm{~cm} \text { (di bawah tinggi lutut } \\
\text { anak). }\end{array}$ \\
\hline & & $\begin{array}{l}\text {. Meniru gerakan senam sederhana seperti menirukan gerakan pohon, kelinci } \\
\text { melompat) }\end{array}$ \\
\hline
\end{tabular}

Kemudian mulai umur 6 tahun anak mulai masuk pada perkembangan sekolah dasar. Perkembangan anak usia sekolah dasar disebut juga perkembangan masa pertengahan dan akhir anak yang merupakan kelanjutan dari masa awal anak. Permulaan masa pertengahan dan akhir ini ditandai dengan terjadinya perkembangan fisik, motorik, kognitif, dan psikososial anak. Masalah mengenai konsep perkembangan ini, akan menjadi kompleks ketika ada satu tahap perkembangan yang terlewati karena kurangnya pemahaman, sehingga pemahaman mengenai hal tersebut pun menjadi sangat penting untuk di pahami.

Perkembangan fisik masa awal anak-anak dan masa akhir anak- anak meliputi ${ }^{8}$;

\begin{tabular}{|l|l|l|}
\hline & Masa awal anak anak 3-6 tahun & $\begin{array}{l}\text { Masa akhir anak anak (6-12 } \\
\text { tahun) }\end{array}$ \\
\hline Tinggi badan & $\begin{array}{l}\text { Pertambahan tinggi badan } \\
\text { Setiap tahun rata rata 3 Inci }\end{array}$ & $\begin{array}{l}\text { Kenaikan per tahun 2-3 } \\
\text { inci, perempuan 11 tahun } \\
\text { tinggi badan 58, dan laki } \\
\text { laki 57,5 inci }\end{array}$ \\
\hline Berat badan & $\begin{array}{l}\text { Pertambahan berat badan setiap } \\
\text { tahun 3 } 3 \text { pon. anak } \\
\text { perempuan rata rata 48,5 pon } \\
\text { dan anak laki laki 49 pon }\end{array}$ & $\begin{array}{l}\text { Kenaikan berat lebih } \\
\text { bervariasi, perempuan 11 } \\
\text { tahun berat badan 88,5 pon, } \\
\text { laki laki 85,5 }\end{array}$ \\
\hline $\begin{array}{l}\text { Perbandingan } \\
\text { bagian tubuh }\end{array}$ & $\begin{array}{l}\text { Wajah tetap kecil, leher lebih } \\
\text { panjang, perut rata, dada lebih } \\
\text { bidang dan rata, tangan dan dan } \\
\text { kaki tumbuh lebih besar }\end{array}$ & $\begin{array}{l}\text { Kepala masih lebih besar } \\
\text { daripada bagian tubuh } \\
\text { lainya, Dahi melebar dan } \\
\text { rata, mulut dan rahang } \\
\text { membesar, bibir berisi, } \\
\text { hidung lebih besar dan }\end{array}$ \\
\hline
\end{tabular}

\footnotetext{
${ }^{8}$ Liat Hurlock, Elizabeth B, Developmental P sychology , 1980, Terj. Istiwidayanti dan Soedjarwo, P sikologi P erkembangan Sepanjang Rentang Kehidupan , Jakarta: Erlangga, 110 \& 149
} 


\begin{tabular}{|l|l|l|}
\hline & & $\begin{array}{l}\text { berbentuk, badan lebih } \\
\text { langsing }\end{array}$ \\
\hline Postur tubuh & $\begin{array}{l}\text { Tampak jelas dalam awal anak } \\
\text { anak, ada yang posturnya } \\
\text { gemuk lembek, kuat berotot, } \\
\text { dan ada lagi yang kurus }\end{array}$ & $\begin{array}{l}\text { Anak yang mesomorfik } \\
\text { tumbuh lebih cepat dari } \\
\text { padaektomorfik atau } \\
\text { endomorfik dan lebih cepat } \\
\text { menjadi pubertas. }\end{array}$ \\
\hline Tulang dan otot & $\begin{array}{l}\text { Otot menjadi lebih besar dan } \\
\text { kuat dan lebih berat, sehingga } \\
\text { anak lebih kurus meskipun } \\
\text { beratnya bertambah }\end{array}$ & $\begin{array}{l}\text { Badan memanjang lengan } \\
\text { dan tungakai memanjang } \\
\text { tangan dan kaki dengan } \\
\text { lambat tumbuh membesar. }\end{array}$ \\
\hline Lemak & $\begin{array}{l}\text { Anak yang gemuk lebih banyak } \\
\text { jaringan lemaknya daripada } \\
\text { jaringan otot, yang berotot } \\
\text { mempunyai jaringan otot lebih } \\
\text { banyak daripada jaringan lemak }\end{array}$ & $\begin{array}{l}\text { Pada anak yang berbentuk } \\
\text { endomorfik jaringan } \\
\text { lemaknya lebih banyak } \\
\text { daripada jaringan otot } \\
\text { sedangkan pada tubuh } \\
\text { mesomorfik keadaanya } \\
\text { terbalik. }\end{array}$ \\
\hline Gigi & $\begin{array}{l}\text { Selama 4-6 bulan pertama, } \\
\text { empat gigi bayi yang terakhir, } \\
\text { geraham belakang muncul, } \\
\text { selama setengah tahun terahir } \\
\text { gigi mulai tanggal } \\
\text { digantikan gigi tetap }\end{array}$ & $\begin{array}{l}\text { Pada masa permulaan } \\
\text { pubertas sudah mempunyai } \\
20 \text { gigi tetap }\end{array}$ \\
\hline
\end{tabular}

Pertumbuhan dan perkembangan fisik anak menentukan keterampilan anak bergerak. Pertumbuhan dan perkembangan mempengaruhi cara memandang dirinya sendiri dan orang lain, yang berdampak dalam melakukan penyesuaian dengan dirinya dan orang lain.

Perkembangan motorik pada anak usia sekolah dasar menurut Desmita, ${ }^{9}$ yaitu 1) Mulai usia 6 tahun sudah berkembang koordinasi antara mata dan tangan (visio motoric) yang dibutuhkan untuk membidik, menyepak, melempar, dan menangkap, 2) Usia 7 tahun, tangan anak semakin kuat dan anak lebih menyukai menggunakan pensil daripada krayon untuk melukis, 3) Usia 8 sampai 10 tahun, anak dapat menggunakan tangan secara bebas, mudah, dan tepat. Koordinasi motorik halus berkembang, sehingga anak dapat menulis dengan baik, ukuran huruf menjadi lebih kecil dan rata, 3) Usia 10 sampai 12 tahun, anak-anak mulai memiliki keterampilan keterampilan manipulatif menyerupai kemampuan orang dewasa. Mereka mulai menampilkan gerakan-gerakan kompleks, rumit, dan cepat yang diperlukan untuk menghasilkan karya kerajinan yang berkualitas atau memainkan alat musik tertentu

\footnotetext{
${ }^{9}$ Desmita.. Psikologi Perkembangan. Bandung: PT Remaja Rosdakarya.2012, 26
} 
Berikut beberapa perkembangan motorik (kasar maupun halus) selama periode ini, antara lain:

\begin{tabular}{|c|c|}
\hline \multicolumn{2}{|c|}{ Kemampuan motorik } \\
\hline Anak usia $6^{\text {th }}$ & Anak usia $7^{\text {th }}$ \\
\hline Ketangkasan meningkat & Mulai membaca dengan lancar \\
\hline Melompat tali & Cemas terhadap kegagalan \\
\hline Bermain sepeda & Kadang malu atau sedih \\
\hline Menguraikanobjek-objek dengan gambar & $\begin{array}{l}\text { Peningkatan minat pada bidang } \\
\text { sepiritual }\end{array}$ \\
\hline Mungkin bertindak menentang & \\
\hline \multicolumn{2}{|c|}{ Kemampuan motorik } \\
\hline Anak usia 8-9 ${ }^{\text {th }}$ & Anak usia $10-12^{\text {th }}$ \\
\hline $\begin{array}{l}\text { Kecepatan dan kehalusan aktivitas motorik } \\
\text { meningkat }\end{array}$ & $\begin{array}{l}\text { Perubahan sikap berkaitan dengan } \\
\text { postur tubuh, puberitas mulai } \\
\text { nampak }\end{array}$ \\
\hline $\begin{array}{l}\text { Mampu menggunakan peralatan rumah } \\
\text { tangga }\end{array}$ & $\begin{array}{l}\text { Mampu melakukan aktivitas rumah } \\
\text { tangga, seperti mencuci, } \\
\text { menjemur, dan lain-lain. }\end{array}$ \\
\hline Keterampilan lebih individual & $\begin{array}{l}\text { Keinginan untuk menyenangkan } \\
\text { orangtua }\end{array}$ \\
\hline Ingin terlibat dalam sesuatu & Mula tertarik dengan lawan jenis \\
\hline Menyukai kelompok dan mode & \\
\hline Mencari teman secara aktif & \\
\hline
\end{tabular}

Selain perkembangan fisik dan motorik, Hurlock ${ }^{10}$ mengemukakan ada empat keterampilan dasar yang perlu dikuasai anak SD/ MI pada masa anak akhir yaitu: keterampilan menolong diri sendiri, keterampilan menolong orang lain (sosial), keterampilan bermain, dan keterampilan bersekolah (skolastik).

Pertumbuhan fisik peserta didik usia SD/MI lebih lambat dibandingkan dengan tingkat pertumbuhan masa sebelumnya (masa bayi dan TK awal) dan sesudahnya (masa puber dan

${ }^{10}$ Hurlock, Elizabeth B, Developmental... 160 
remaja). Jadwal waktu pertumbuhan fisik tiap anak tidak sama, ada yang berlangsung cepat, sedang atau lambat. Banyak faktor yang mempengaruhi perkembangan fisik anak antara lain:

1) Faktor keturunan; dapat menyebabkan anak menjadi gemuk dari pada anak lainnya. Perbedaan ras suku bangsa (orang Amerika, Eropa, dan Australia cenderung lebih tinggi dari pada orang Asia).

2) Faktor lingkungan; dapat membantu menentukan tercapai tidaknya perwujudan potensi keturunan anak tersebut. Lingkungan lebih banyak pengaruhnya terhadap berat tubuh daripada tinggi tubuh.

3) Jenis kelamin; anak laki-laki cenderung lebih tinggi dan lebih berat dibandingkan dengan anak perempuan, kecuali pada usia 12-15 tahun.

4) Gizi dan kesehatan; anak yang memperoleh gizi cukup biasanya lebih tinggi tubuhnya dan relatif lebih cepat mencapai masa puber dibandingkan dengan anak yang bergizi kurang. Anak yang sehat dan jarang sakit biasanya mempunyai tubuh sehat dan lebih berat dibanding dengan anak yang sering sakit.

5) Status sosial dan ekonomi; fisik anak dari kelompok ekonomi rendah cenderung lebih kecil dibandingkan dengan keluarga ekonomi cukup atau tinggi. Keadaan status ekonomi mempengaruhi peran keluarga dalam memberi makan, gizi dan pemeliharan kesehatan serta kegiatan pekerjaan yang dilakukan anak.

6) Gangguan emosional; anak yang sering mengalami gangguan emosional akan menyebabkan terbentuknya steroid adrenalin yang berlebihan. Hal ini menyebabkan berkurangnya hormon pertumbuhan pada kelenjar pituitary, akibatnya anak mengalami keterlambatan perkembangan memasuki masa puber. Bagi anak usia SD atau MI, reaksi yang diperlihatkan orang lain terutama oleh teman-teman sebayanya terhadap ukuran dan proporsi tubuhnya mempunyai makna penting. Apabila ukuran-ukuran dan proporsi tubuh anak berbeda jauh dengan teman sebayanya anak akan merasa kelainan, tidak mampu dan rendah diri. ${ }^{11}$

\section{Problem Perkembangan Fisik dan Penanganannya}

Dalam proses perkembangannya, perkembangan fisik akan mempengaruhi kemampuan motorik. Perkembangan fisik lazimnya ditandai dengan perubahan pada tinggi dan berat badan, serta bentuk tubuh dan juga perkembangan otak. Jika perkembangan fisik anak berkembang dengan baik tentu akan berpengaruh pada keterampilan motoriknya. Begitupun dengan anak yang perkembangan fisiknya mengalami gangguan, akan berdampak pada terganggunya kemampuan motorik anak tersebut. Gangguan fisik dan motorik anak yang mengalami kelainan atau cacat

\footnotetext{
${ }^{11}$ Eric Burhaein, Aktivitas Fisik Olahraga untuk Pertumbuhan dan Perkembangan Siswa SD, Indonesian Journal of Primary Education Vol 1 No 1 (2017)
} 
yang menetap pada alat gerak (tulang) sedemikian rupa sehingga memerlukan pelayanan pendidikan khusus. Untuk mengatasai gangguan perkembangan sejak dini diperlukan pemeriksaan yang diawali sejak dalam kandungan serta asupan gizi yang harus diperhatikan. Adapun hal yang dapat dilakukan agar manjadikan keterbatasan tersebut bukan suatu kekurangan yaitu memberikan motivasi dan pendidikan bagi penyandang keterbatasan fisik dan lainya agar mereka mempunyai kemampuan selayaknya orang yang memiliki perkembangan secara normal.

\section{Jenis Jenis permasalahan fisik anak}

Jenis-jenis permasalahan pada anak digolongkan menjadi tiga yaitu masalah fisik, psikiososial, dan masalah belajar ${ }^{12}$.Adapun permasalahan fisik pada anak berkaitan dengan sistem koordinasi dan pancaindra anak. Anak yang mengalami gangguan pada pancaindra, sistem koordinasi gerak, atau mengalami hambatan dalam perkembangan fisik motorik dapat dikatakan mengalami masalah secara fisik. Beberapa permasalahan fisik pada anak antara lain :

a. Masalah Motorik

Masalah motorik terbagi menjadi dua bagian yakni motorik kasar dan motorik halus. Motorik kasar merupakan keterampilan menggerakkan tubuh secara harmonis seperti contohnya berlari, dan mempengaruhi perkembangan motorik halus. Motorik halus sendiri dapat diartikan sebagai keterampilan dalam mengkoordinasikan otot-otot halus seperti menggunting, mewarnai, meronce, menggambar, dan lain sebagainya.

Permasalahan yang sering muncul pada anak adalah belum sempurnanya koordinasi sistem gerak sehingga anak belum mampu mengontrol motorik kasarnya. Kemampuan anak menguasai keterampilan motorik kasar dan halus dibutuhkan anak untuk persiapan menulis, menggunting, menari, mewarnai dan sebagainya.

b. Masalah Penglihatan

Indra penglihatan berpengaruh besar terhadap perkembangan anak, apabila indra penglihatan mengalami gangguan maka perkembangan anak akan terhambat. Melalui indra penglihatan anak dapat membedakan warna dan bentuk yang akan menunjang perkembangan kognitifnya.

Permasalahan yang ditimbulkan dari gangguan penglihatan juga menyebabkan gangguan ingatan. Gangguan ingatan tersebut antara lain a) Tidak mampu menyebutkan benda tanpa ada bendanya b) Tidak mampu menguraikan benda-benda yang dilihat dari beberapa aspek, misalnya bentuk, warna, fungsi dan sebagainya. c) Tidak mampu mencari bagian yang hilang dari suatu bentuk atau gambar. d) Tidak mampu mengurutkan kembali satu seri gambar yang diacak.

\footnotetext{
12 Saomah, Aas. 2004. Permasalahan-permasalahan Anak dan Upaya Penyelesaiannya. Makalah Tidak Diterbitkan. Bandung : Universitas Pendidikan Indonesia
} 
c. Masalah Pendengaran

Gangguan pendengaran pada anak bukan berarti anak mengalami tuli, akan tetapi anak mengalami kesulitan dalam membedakan suatu bunyi atau suara. Sebagian besar orangtua menganggap masalah pendengaran adalah masalah yang sepele, sehingga masalah yang awalnya kecil justru menjadi gangguan yang sulit disembuhkan.

d. Masalah Berbahasa

Masalah berbahasa dan berbicara pada anak diawali dari ketidakmampuan mendengar dan memahami bahasa lisan yang diucapkan orang-orang disekelilingnya. Selain itu budaya yang masih menjamur dikalangan orangtua adalah seringnya orang tua tidak memberi kesempatan kepada anak untuk mengutarakan isi hatinya, sehingga secara tidak langsung hal tersebut menghambat perkembangan bahasa anak. Masalah lain yang terkait dengan gangguan berbahasa adalah berbicara tidak jelas dan gagap.

e. Kegemukan. anak yang memiliki berat tubuh diatas 20 persen diatas- rata anak seusianya dan anak iini akan mudah terkena diabetes dan penyakit lain maka dari itu perlu pengaturan pola makan karna pola makan yang salah akan menetap dan penyakit kegemukan akan mengganggu sepanjang hidupnya

f. tangan kidal. Tidakada alasan fisik mengapa tangan kidal menjadi permasalahan dalam perkembangan fisik, hanya saja sesuatu yang berbeda pada masa kanak - kanak akan menyebabkan anak itu merasa rendah diri.

dan masih banyak lagi masalah lain dalam perkembangan fisik

\section{Faktor faktor yang mempengaruhi permasalahan pada anak}

Dari beberapa permasalahan perkembangan fisik di atas, ada dua faktor yang mempengaruhi permasalahan pada anak yakni faktor internal dan faktor eksternal. Faktor internal yaitu faktor-faktor yang berasal dari dalam diri inidivu seperti Kesehatan menurun yang memiliki resiko terhadap perkembangan fisik motorik anak. seperti Kelainan pada sistem otak, genetik, dan saraf. Kecerdasan. sedangkan faktor eksternal adalah faktor-faktor dari luar seperti lingkungan tempat anak berada. antara lain:

a) Keluarga sangat mempengaruhi perkembangan anak karena keluarga adalah pijakan dasar anak untuk tumbuh sehingga mempunyai andil besar dalam perkembangan anak, selain itu pola asuh orang tua dan keadaan sosial ekonomi keluarga sangat berpengaruh terhadap perkembangan anak.

b) Lingkungan sekolah meliputi cara mengajar guru dan proses belajar mengajar yang diterapkan disekolah. 
c) Masyarakat meliputi teman sepermainan atau teman sebaya yang dapat mempengaruhi perkembangan anak, karena lingkungan berpengaruh besar terhadap pembentukan karakter seorang anak.

d) Media sangat berpengaruh besar terhadap perkembangan anak, terlebih lagi media televisi yang menyajikan berbagai acara dan hiburan yang tentunya membawa dampak positif dan negatif bagi perkembangan anak. ${ }^{13}$

\section{Langkah langkah dan tekhnik penanganan permasalahan fisik anak}

Untuk mengetahui permasalahan fisik yang terdapat pada diri anak bisa dilakukan dengan DDTK (deteksi dini tumbuh kembang) anak, yaitu bisa meliputi tes dan non tes. Tes merupakan salah satu alat bantu yang dapat dipergunakan untuk mengidentifikasi permasalahan anak yang bersifat standar/baku. Bentuk tes ini dapat berupa pertanyaan-pertanyaan atau tugas -tugas yang harus dijawab atau dikerjakan anak serta dibatasi oleh waktu. Di antara beragam jenis tes yang banyak dipergunakan, di antaranya adalah: tes bakat; . inteligensi;. prestasi; . diagnostik;. dan lainlain, kemudian Teknik non tes biasanya dipergunakan untuk mengidentifikasi permasalahan anak dengan cara mengamati penampilan serta perilaku anak dalam aktivitas kesehariannya sehingga cenderung lebih fleksibel bila dibandingkan dengan teknik tes. Di samping itu, dipergunakan pula kumpulan hasil karya dan pekerjaan anak selama periode waktu tertentu

Adapun Penanganan masalah anak dapat dilakukan dengan mengikuti langkah-langkah sebagai berikut. a.) Identifikasi kasus, yakni upaya untuk menandai subjek (anak) yang diperkirakan mengalami masalah. b). Identifikasi masalah, yakni upaya mengetahui inti permasalahan yang dihadapi anak. c). Diagnosis, merupakan langkah untuk mengidentifikasi karakteristik serta faktor penyebab masalah yang dialami anak. d.) Prognosis, merupakan langkah untuk merumuskan alternatif upaya bantuan sesuai dengan karakteristik permasalahan yang dialami. e). Treatment, merupakan upaya pemberian bantuan itu sendiri. f). Tindak lanjut, dilakukan sebagai bentuk evaluasi terhadap upaya pemberian bantuan yang telah dilakukan serta kemungkinan penggunaan langkah-langkah berikutnya. ${ }^{14}$

\section{Kesimpulan}

Perkembangan fisik adalah pertumbuhan dan perubahan yang terjadi pada tubuh seseorang. Perubahan yang paling jelas terlihat adalah perubahan pada bentuk dan ukuran tubuh seseorang. setiap tahap perkembangan anak mempunyai karakteristik yang berbeda kalau anak usia sekolah

\footnotetext{
${ }^{13}$ Saomah, Aas. Permasalahan anak dan upaya menannganinya, Makalh Disajikan pada Pendidikan dan Pelatihan tentang Strategi Peningkatan Penanganan Kesulitan Belajar Anak Taman Kanak-Kanak bagi para Guru TK di Kelurahan Melong, Cimahi Tahun 2004

${ }^{14}$ Saomah, Aas. Permasalahan anak dan upaya menannganinya, Makalh Disajikan pada Pendidikan dan

Pelatihan tentang Strategi Peningkatan Penanganan Kesulitan Belajar Anak Taman Kanak-Kanak bagi para Guru TK di Kelurahan Melong, Cimahi Tahun 2004
} 
dasar karakteristinya antara lain : senang bergerak, senang aktifitas kelompok dan senang praktek langsung

Perkembangan fisik anak yang baik akan melalui tahapan tahapan perkembangan yang dilalui anak mulai dari usia 0 sampai dengan 12 tahun. namun ada banyak faktor yang mempengaruhi perkembnagan fisik antara lain : faktor keturunan, lingkungan, kelamin, kesehatan/gizi, status sosial/ekonomi dan gangguan emosional

Jenis-jenis permasalahan perkembangan pada anak digolongkan menjadi tiga yaitu masalah fisik, psikio-sosial, dan masalah belajar. Adapun masalah perkembangan fisik pada anak meliputi masalah motorik, penglihatan, pendengaran dan masalah bahasa. Namun beberapa masalah diatas dapat di tangani dengan beberapa langkah antara lain : identifikasi kasus, diagnosis, prognisis, treatment dan tindak lanjut

\section{Daftar Pustaka}

Abdul Alim. 2009. Permainan Mini Tenis untuk pembelajaran pendidikan Jasmani Olahraga dan Kesehatan Siswa di Sekolah Dasar. JPJI. Vol 6. No. 2. Nov

Desmita. 2012. Psikologi Perkembangan. Bandung: PT Remaja Rosdakarya.

Eric Burhaein, 2017, Aktivitas Fisik Olahraga untuk Pertumbuhan dan Perkembangan Siswa SD, Indonesian Journal of Primary Education Vol 1 No 1

Hurlock, Elizabeth 1980, B, Developmental P sychology , 1980, Terj. Istiwidayanti dan Soedjarwo, Psikologi Perkembangan Sepanjang Rentang Kehidupan, Jakarta: Erlangga

Masganti, 2012, Perkembangan Peserta Didik, Medan: Perdana Publishing, Pengembangan Program Stimulasi Perkembangan Motorik Kasar Anak Usia 0 - <3 Tahun,

BPPAUDNI Regional II Surabaya, 2014

Rini Hildayani. 2016, Psikologi Perkembangan Anak. Tangerang: Universitas Terbuka.

Saomah, Aas. 2004. Permasalahan-permasalahan Anak dan Upaya Penyelesaiannya. Makalah Tidak Diterbitkan. Bandung : Universitas Pendidikan Indonesia

Yusuf, S. 2014. Psikologi Perkembangan Anak dan Remaja. Bandung: PT Remaja Rosdakarya 